American Journal of Agricultural and Biological Science 1 (4): 58-65, 2006

ISSN 1557-4989

(C) 2006 Science Publications

\title{
Morpho-physiological Differences of the Spermatheca of Attini Ants (Hymenoptera: Myrmicinae)
}

\author{
${ }^{1}$ Gabriela Ortiz and ${ }^{2}$ Maria Izabel Camargo-Mathias \\ ${ }^{1,2}$ Instituto de Biociências, Departamento de Biologia da UNESP. Avenida 24-A, n 1515 Cep: \\ 13506-900, Rio Claro-SP-Brasil
}

\begin{abstract}
The insect's spermatheca store the spermatozoa from the time of copulation until the fertilization of the eggs and consists of a sac, usually associated to glands. The ant species Atta laevigata, Atta sexdens sexdens, Atta sexdens piriventris, Acromyrmex coronatus and Cyphomyrmex muelleri are considered pests, as they cause economics losses to several crops. The spermatheca of these species were examined by scanning electron microscopy, histological and histochemical techniques. Their morphology resembled that of a bilobular pouch partially jointed in the central portion. In A. coronatus and C. muelleri it is flatter in shape than those of other species. The external spermathecal gland, groups of secretory cells, was located at the joining point of the two spermathecal lobes of the reservoir. This was observed in A. laevigata, A. s. sexdens and A. coronatus, like a group of cells, while in $C$. muelleri, like filaments. An external associated gland was not observed in $A$. $s$. piriventris, instead secretory cells were arranged in a simple prismatic epithelium internally lining the spermathecal lumen. This epithelium was also observed in A. s. sexdens, although it was restricted to the joining point of the spermathecal lobes. The presence of an internal secretory epithelium in $A$. $s$. piriventris and $A$. s. sexdens suggests that their physiology for the maintenance of spermatozoa in viable conditions for egg fertilization might differ from A. laevigata, A. coronatus and C. muelleri, in which only an external spermathecal gland was observed.
\end{abstract}

Key words: Spermatheca, histology, histochemistry, spermathecal gland, Attini

\section{INTRODUCTION}

The leaf-cutting ants are the main agricultural pests and are represented by some species of the genera Atta and Acromyrmex, which are the most derived of the tribe Attini and whose colonizing success of agricultural crops is attributed to their great voracity and capability to proliferate.

Ant queens live unusually long for insects, which generally have short lives. They store viable spermatozoa for a decade or more and produce workers and reproductives over such long periods, that almost certainly has contributed to the propensity for ants to evolve diverse life histories that been so successful in a wide range of environments.

The ability to store spermatozoa releases from the risk and energy expenditure involved in finding subsequent mates ${ }^{[1]}$. Maintenance of spermatozoa viability can be a critical aspect of female reproduction in insects, yet the mechanisms mediating this phenomenon are poorly understood.

The maintenance of these spermatozoa for such a long time requires the presence of a specialized organ in the queens, known as spermatheca which presents a particular organization for each phylogenetic group that has been studied ${ }^{[2]}$.
The morphology of the insect spermatheca varies from species to species, however it basically consists of storage pouch where asociated glands, called spermathecal glands, can often be observed. When these glands are absent, the actual spermathecal epithelium functions to produce secretions that supply adequate nutrients and conditions for the survival of the spermatozoa $^{[2,3]}$.

Generally, the spermatheca consists of a single sac, but two have been observed in Blaps (Coleoptera) and Phlebotomus (Diptera) and three occur in the most derived flies ${ }^{[2]}$. In ants in general only one spermatheca has been described.

In a variety of insects taxa, females have complex storage organs with multiple compartments ${ }^{[4]}$. A possible function of such multiple compartments is to enable differential spermatozoa storage, that is, the spatial separation of compenting spermatozoa in independent compartments. This separation, in turn, may allow females to use spermatozoa differentially at fertilization.

Insect spermatheca produce glycoproteins or mucopolyssacharides through their glandular secretory cells ${ }^{[5]}$. The mucopolyssacharide secreted by the spermathecal gland has been shown to contain a chemotactic substance responsible for the transport and 
migration of spermatozoa from female bursa copulatrix to the spermatheca in the boll weevil Anthnomus grandis $^{[6]}$. Very small amounts of the secretion from the spermathecal gland affect the motility and fertilizing capacity of spermatozoa ${ }^{[6]}$. The importance of these secretions for fertilization is demonstrated by the fact that the removal of spermathecal gland led to gradual loss of spermatozoa motility and spermathecal emptying $^{[7-9]}$. The main function of these secretions would be to maintain the viability of the spermatozoa during the time of mating until the fertilization of the eggs $^{[10]}$. The spermatozoa of insects become active inside the spermatheca and may remain there for several months or up to several years.

In view of the facts described above and given the economical importance of these insects, the present work had the object of carrying out a study of the spermatheca of queen ants of Atta laevigata, Atta sexdens sexdens, Atta sexdens piriventris, Acromyrmex coronatus and Cyphomyrmex muelleri through the use of the techniques of Scanning Electron Microscopy (SEM), histology and histochemistry. The specific aim of this study is to show a morphological diversity between the spermatheca in ants of the tribe Attini.

\section{MATERIALS AND METHODS}

Were utilized fertilized queens of Atta laevigata (provided by Dr. Odair Corrêa Bueno-Center for the Study of Social Insects-CEIS-UNESP-Rio Claro/SP/Brazil), Atta sexdens sexdens (provided by Dr. Jacques Delabie and collected at CEPLACIlhéus/Bahia/Brazil), Atta sexdens piriventris (provided by Fábio Moreira Link and collected in Santa Maria/RS/Brazil), Acromyrmex coronatus (collected from nests located in the UNESP Campus in Rio Claro/SP) and Cyphomyrmex muelleri (provided by Dr. Ulrich Mueller-University of Texas-Austin/EUA). The equipment utilized in this study were located at the Histology and Electron Microscopy Laboratories of the Department of Biology of the Institute of Biosciences as well as at CEIS-Center for the Study of Social Insects of UNESP-Rio Claro/SP/Brazil.

Scanning Electron Microscopy (SEM): The spermatheca were removed from the $A$. s. sexdens and A. $s$. piriventris queens, fixed en Karnovsky for 24 hours and dehydrated in a graded $70-100 \%$ ethanol and acetone series. The material was critical point dried, sputtered with gold and examined under a Phillips SEM 505.

Histology: The spermatheca from queens of all species were removed, fixed in paraformaldehyde, dehydrated a graded $70-95 \%$ alcohol series and embedded in JB-4 resin at $4^{\circ}$ in the dark. Then they were placed in plastic molds at $4^{\circ} \mathrm{C}$ in order to delay premature polymerization. The plastic molds containing the material were filled with JB-4 resin and polymerization was completed at room temperature. The sections were placed on clean glass slides and air dried. Then they were stained with hematoxylin-eosin, just applied in $A$. s. sexdens and $A$. coronatus.

Histochemistry: Individuals were cold anesthetized and dissected in saline solution. The spermatheca were fixed in paraformaldehyde. Dehydration was performed in a standard alcohol series (70, 80, 90 and 95\%) at 15 minutes intervals. The material was embedded in resin and sectioned to a $3 \mu \mathrm{m}$ thickness. The sections were arrayed on glass slides and stained with PAS/Alcian Blue (for the detection of polysaccharides) just applied in the species $A . s$. sexdens and $A$. s. piriventris, Bromophenol Blue (for protein detection) just applied in the species A. laevigata, $A . s . \operatorname{sexdens,~} A . s$. piriventris and $C$. Muelleri, Ninhidrina Schiff (for protein detection) just applied in the species $A$. laevigata and $A$. s. sexdens, Sudan Black B (for lipids detection) just applied in the species A. laevigata and $A$. s. sexdens and Nile Blue (for lipids detection) just applied in the species $A$. s. sexdens and A. s. piriventris.

\section{RESULTS AND DISCUSSION}

Morphology: The morphological results obtained for the spermatheca of ant queens of $A$. laevigata, $A$. $S$. sexdens, $A$. s. piriventris, $A$. coronatus and $C$. muelleri revealed that in all five species, this structure is located at beginning of the common oviduct of the female reproductive tract and resembles a bilobed pouch partially jointed at the central portion, therefore exhibiting a common lumen (Fig. 1). In A. coronatus and $C$. muelleri, the spermatheca is flatter in shape than those observed in other species (Fig. 1).

Thus, the spermatheca of queens of $A$. laevigata, $A$. s. sexdens, $A$. s. piriventris, $A$. coronatus and $C$. muelleri exhibit a large spermathecal reservoir to store and maintain spermatozoa, in which they remain from mating until egg fertilization (Fig. 1).

The surface of the reservoir of the spermatheca of A. $s$. sexdens and A. s. piriventris is rough and tracheoles are attached into the structure. SEM observations of the internal portion of the reservoir of the spermatheca of these species revealed that this region is internally infolded and irregular, due to the presence of a thick cuticle lining the entire structure (Fig. 2F, G, H, S).

Inside the reservoir of $A$. laevigata, $A$. s. sexdens, A. s. piriventris and C. muelleri examined in this study, we observed filamentous and elongated spermatozoa with a constant diameter (Fig. 2H, S).

Histology and histochemistry: To better compare and visualize, histological and histochemical results are summarized in Table 1. 
Table 1: Histology and histochemistry of the spermatheca of queens of the ants Atta laevigata, Atta sexdens sexdens, Atta sexdens piriventris,

\begin{tabular}{|c|c|c|c|c|c|}
\hline Species & Atta laevigata & $\begin{array}{l}\text { Atta sexdens } \\
\text { Sexdens }\end{array}$ & $\begin{array}{l}\text { Atta sexdens } \\
\text { piriventris }\end{array}$ & $\begin{array}{l}\text { Acromyrmex } \\
\text { Coronatus }\end{array}$ & $\begin{array}{l}\text { Cyphomyrmex } \\
\text { muelleri }\end{array}$ \\
\hline $\begin{array}{l}\text { Spermathecal } \\
\text { gland }\end{array}$ & $\begin{array}{l}\text {-Present as groups of } \\
\text { cells forming acini (Fig. } \\
\text { 1,2 A) } \\
\text {-Round and/or } \\
\text { polygonal-shaped } \\
\text { secretory cells located at } \\
\text { the joining point of } \\
\text { spermathecal lobes (Fig. } \\
\text { 1, 2 A) } \\
\text {-Round-shaped nuclei } \\
\text { (Fig. 1, 2 A) } \\
\text {-Ninhydrin Schiff }+++ \\
\text { (Fig. 2 A) } \\
\text {-Sudan Black B + }\end{array}$ & $\begin{array}{l}\text {-Present as groups of } \\
\text { cells forming acini (Fig. } \\
\text { 1, } 2 \text { I, J, K) } \\
\text {-Secretory cells varying } \\
\text { from cubic to prismatic } \\
\text { shaped; cells may be } \\
\text { rounder when located } \\
\text { near the periphery (Fig. } \\
\text { 1, } 2 \text { I, J, K) } \\
\text {-Large nuclei consistent } \\
\text { with the cell } \\
\text { morphology and with } 2 \\
\text { to } 3 \text { nucleoli (Fig. 1, } 2 \text { I, } \\
\text { J, K) } \\
\text {-Presence of extracelular } \\
\text { cananiculli of } \\
\text { considerable caliber } \\
\text { internally lined with a } \\
\text { thick cuticle (Fig. } 2 \text { I) } \\
\text {-Ninhydrin Schiff +++ } \\
\text { (Fig. } 2 \text { J) } \\
\text {-PAS/Alcian Blue + } \\
\text { (Fig. } 2 \text { K) } \\
\text {-Sudan Black B- }\end{array}$ & -Absent & $\begin{array}{l}\text {-Present as filaments with } \\
\text { a visible central lumen } \\
\text { (Fig. 1, 2 W) } \\
\text {-Round to prismatic } \\
\text { shaped secretory cells } \\
\text { (Fig. 1, 2 W) } \\
\text {-Spherical nuclei located } \\
\text { in the median region of } \\
\text { cells with evident nucleoli } \\
\text { (Fig. 1, 2 W) }\end{array}$ & $\begin{array}{l}\text {-Present as filaments } \\
\text { with a visible central } \\
\text { lumen containing } \\
\text { secretion (Fig. 1, } 2 \\
\text { X) } \\
\text {-Cubic shaped } \\
\text { secretory cells (Fig. } \\
1,2 \mathrm{X} \text { ) } \\
\text {-Nuclei consistent } \\
\text { with the cell } \\
\text { morphology and } \\
\text { with only } 1 \\
\text { nucleolus (Fig. 1, } 2 \\
\text { X) } \\
\text {-Bromophenol Blue } \\
+++ \text { (Fig. } 2 \mathrm{X} \text { ) }\end{array}$ \\
\hline & Atta laevigata & $\begin{array}{l}\text { Atta sexdens } \\
\text { sexdens }\end{array}$ & $\begin{array}{l}\text { Atta sexdens } \\
\text { Piriventris }\end{array}$ & $\begin{array}{l}\text { Acromyrmex } \\
\text { Coronatus }\end{array}$ & $\begin{array}{l}\text { Cyphomyrmex } \\
\text { muelleri }\end{array}$ \\
\hline $\begin{array}{l}\text { Internal } \\
\text { secretory } \\
\text { epithelium }\end{array}$ & -Absent & $\begin{array}{l}\text {-Simple secretory } \\
\text { epithelium consisted of } \\
\text { prismatic cells and very } \\
\text { elongated nuclei located } \\
\text { only joining point of the } \\
\text { spermathecal lobes (Fig. } \\
\text { 1, } 2 \mathrm{~L}, \mathrm{M}, \mathrm{N}, \mathrm{O} \text { ) } \\
\text {-Bromophenol Bluel } \\
\text { +++ (Fig. } 2 \mathrm{M} \text { ) } \\
\text {-PAS/Alcian Blue-(Fig. } \\
2 \mathrm{~N} \text { ) } \\
\text {-Nile Blue + (Fig. 2 O) }\end{array}$ & $\begin{array}{l}\text {-Simple secretory } \\
\text { epithelium consisted of } \\
\text { tall and narrow } \\
\text { prismatic cells and } \\
\text { nuclei consistent with } \\
\text { this morphology. This } \\
\text { epithelium, however, } \\
\text { differentiates at the } \\
\text { joining point of the } \\
\text { lobes and cells become } \\
\text { even larger (Fig. 1, } 2 \text { T, } \\
\text { U, V) } \\
\text {-Bromophenol Blue +++ } \\
\text { (Fig. } 2 \text { T) } \\
\text {-PAS/Alcian Blue-(Fig. } \\
2 \text { U) } \\
\text {-Nile Blue +++ (Fig. } 2 \\
\text { V) }\end{array}$ & -Absent & -Absent \\
\hline $\begin{array}{l}\text { Reservoir } \\
\text { wall }\end{array}$ & $\begin{array}{l}\text {-Thin } \\
\text {-Consisted of a simple } \\
\text { epithelium varying from } \\
\text { squamous to cubic (Fig. } \\
\text { 1, 2 B) } \\
\text {-Ninhydrin Schiff +++ } \\
\text { (Fig. } 2 \text { A, B) } \\
\text {-Sudan Black B + (Fig. } \\
\text { 2 E) } \\
\text {-At the joining point of } \\
\text { spermathecal lobes, this } \\
\text { epithelium exhibits } \\
\text { several layers of oval or } \\
\text { polygonal cells (Fig. } 2 \\
\text { C) } \\
\text {-Ninhydrin Schiff +++ } \\
\text { (Fig. 2 C) } \\
\text { Sudan Black B- }\end{array}$ & $\begin{array}{l}\text {-Thin, except at the } \\
\text { joining point of } \\
\text { spermathecal lobes, due } \\
\text { to the presence of the } \\
\text { prismatic secretory } \\
\text { epithelium (Fig. 1, 2 L, } \\
\mathrm{N}, \mathrm{O} \text { ) } \\
\text {-Consisted of a simple } \\
\text { lining epithelium } \\
\text { varying from cubic to } \\
\text { squamous (Fig. 1, 2 M) } \\
\text {-Bromophenol Blue +++ } \\
\text { (Fig. } 2 \mathrm{M} \text { ) } \\
\text {-PAS/Alcian Blue-(Fig. } \\
2 \mathrm{~N} \text { ) }\end{array}$ & $\begin{array}{l}\text {-Thick } \\
\text {-Consisted of a simple } \\
\text { prismatic secretory } \\
\text { epithelium (Fig. 1, } 2 \mathrm{~T} \text {, } \\
\mathrm{U}, \mathrm{V} \text { ) } \\
\text {-Bromophenol Blue +++ } \\
\text { (Fig. } 2 \text { T) } \\
\text {-PAS/Alcian Blue-(Fig. } \\
2 \mathrm{U} \text { ) } \\
\text {-Nile Blue +++ (Fig. } 2 \\
\text { V) }\end{array}$ & $\begin{array}{l}\text {-Thin } \\
\text {-Consisted of a simple } \\
\text { squamous epithelium } \\
\text { exhibiting cells with } \\
\text { flattened nuclei (Fig. 1, } 2 \\
\text { W) }\end{array}$ & $\begin{array}{l}\text {-Thin } \\
\text {-Consisted of a } \\
\text { simple squamous } \\
\text { epithelium (Fig. 1, } \\
2 \mathrm{X} \text { ) } \\
\text {-Bromophenol } \\
\text { Blue + (Fig. } 2 \mathrm{X} \text { ) }\end{array}$ \\
\hline
\end{tabular}


Table 1: Contd.

\begin{tabular}{|c|c|c|c|c|c|}
\hline Species & Atta laevigata & $\begin{array}{l}\text { Atta sexdens } \\
\text { sexdens }\end{array}$ & $\begin{array}{l}\text { Atta sexdens } \\
\text { piriventris }\end{array}$ & $\begin{array}{l}\text { Acromyrmex } \\
\text { coronatus }\end{array}$ & $\begin{array}{l}\text { Cyphomyrmex } \\
\text { muelleri }\end{array}$ \\
\hline $\begin{array}{l}\text { Cuticle found } \\
\text { internally } \\
\text { lining the } \\
\text { spermatheca }\end{array}$ & $\begin{array}{l}\text {-Thick in most of its } \\
\text { area (Fig. 1, 2 A, B) } \\
\text {-Ninhydrin Schiff +++ } \\
\text { (Fig. 2 A, B) } \\
\text {-Sudan Black B + (Fig. } \\
\text { 2 E) } \\
\text {-Thin on the stratified } \\
\text { epithelium (Fig. 2 C) }\end{array}$ & $\begin{array}{l}\text {-Thick throughout (Fig. } \\
\text { 1, 2 M, N, R) } \\
\text {-Bromophenol Blue +++ } \\
\text { (Fig. 2 M) } \\
\text {-PAS/Alcian Blue ++ } \\
\text { (Fig. 2 N) } \\
\text {-Sudan Black B + (Fig. } \\
\text { 2 R) }\end{array}$ & $\begin{array}{l}\text {-Thick, but it becomes } \\
\text { thinner in the joining } \\
\text { point of the lobes where } \\
\text { the epithelium } \\
\text { differentiates (Fig. 1, } 2 \\
\text { T, U) } \\
\text {-Bromophenol Blue+ } \\
\text { (Fig. } 2 \text { T) } \\
\text {-PAS/Alcian Blue ++ } \\
\text { (Fig. } 2 \text { U) } \\
\text {-Nile Blue-(Fig. 2 V) }\end{array}$ & -Thin & $\begin{array}{l}\text {-Thin (Fig. 1, } 2 \mathrm{X} \text { ) } \\
\text {-Bromophenol } \\
\text { Blue + (Fig. } 2 \mathrm{X} \text { ) }\end{array}$ \\
\hline $\begin{array}{l}\text { Musculature } \\
\text { found } \\
\text { externally } \\
\text { surrounding } \\
\text { the } \\
\text { spermatheca }\end{array}$ & $\begin{array}{l}\text {-Several layers (Fig. 1, } 2 \\
\text { B) } \\
\text {-Ninhydrin Schiff +++ } \\
\text { (Fig. 2 B) } \\
\text {-Sudan Black B- }\end{array}$ & $\begin{array}{l}\text {-Several layers (Fig. 1, } 2 \\
\text { M) } \\
\text {-Bromophenol Blue +++ } \\
\text { (Fig. 2 M) } \\
\text {-PAS/Alcian Blue + } \\
\text {-Sudan Black B + }\end{array}$ & $\begin{array}{l}\text {-Several layers (Fig. 1, } 2 \\
\text { U, V) } \\
\text {-Bromophenol Blue +++ } \\
\text {-PAS/Alcian Blue +++ } \\
\text { (Fig. 2U) } \\
\text {-Nile Blue-(Fig. 2 V) }\end{array}$ & -Few layers (Fig. 1, $2 \mathrm{~W}$ ) & $\begin{array}{l}\text {-Few layers (Fig. } \\
1,2 \mathrm{X} \text { ) } \\
\text {-Bromophenol } \\
\text { Blue + (Fig. } 2 \mathrm{X} \text { ) }\end{array}$ \\
\hline $\begin{array}{l}\text { Morphology } \\
\text { of the } \\
\text { spermatozoa }\end{array}$ & $\begin{array}{l}\text {-Elongated, no } \\
\text { distinction between head } \\
\text { and tail (Fig. 1, 2 D) } \\
\text {-Bromophenol Blue +++ } \\
\text { (Fig. 2 D) }\end{array}$ & $\begin{array}{l}\text {-Elongated, no } \\
\text { distinction between head } \\
\text { and tail (Fig. 1, 2 P, Q, } \\
\text { R) } \\
\text {-Bromophenol Blue +++ } \\
\text { (Fig. 2 P) } \\
\text {-PAS/Alcian Blue ++ } \\
\text { (Fig. 2 Q) } \\
\text {-Sudan Black B ++ (Fig. } \\
\text { 2 R) } \\
\text { - Medium positive reaction }\end{array}$ & $\begin{array}{l}\text {-Elongated, no } \\
\text { distinction between head } \\
\text { and tail (Fig. 1, 2 S) }\end{array}$ & $\begin{array}{l}\text {-Elongated, no distinction } \\
\text { between head and tail (Fig. } \\
\text { 1) }\end{array}$ & $\begin{array}{l}\text {-Elongated, no } \\
\text { distinction } \\
\text { between head and } \\
\text { tail (Fig. 1, 2 X) } \\
\text {-Bromophenol } \\
\text { Blue +++ (Fig. } 2 \\
\text { X) }\end{array}$ \\
\hline
\end{tabular}
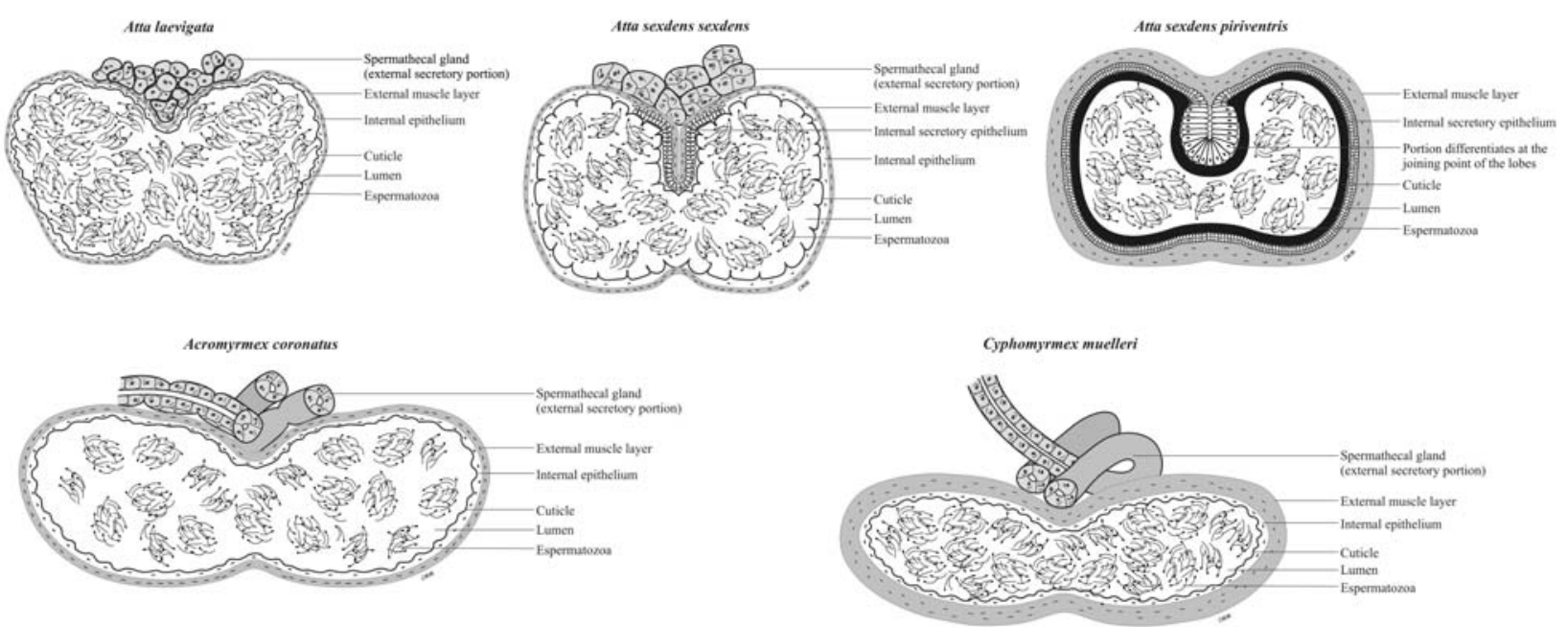

Fig. 1: Schematic diagram showing the bilobed sac morphology of the spermatheca of the ants Atta laevigata, Atta sexdens sexdens, Atta sexdens piriventris, Acromyrmex coronatus and Cyphomyrmex mueller

Aspects of the internal anatomy of ants still remain mostly unknown, as most studies on these insects are focused on control aspects, especially in ants of the genus Atta, considered pests. Although of considerable importance, few studies have been conducted to describe the morphology of the spermatheca of these insects.

In general, the spermatheca of ants has been considered an important structure for their adaptive success, as it receives and stores sperm from mating until egg fertilization, in addition to being a source of origin of new individuals of a colony.
The spermatheca is an organ usually described as a pouch, to which glands might be associated with and discharge their secretion into. These glands are termed spermathecal glands and play a role in the production of secretions that allow the maintenance of a microhabitat with an adequate $\mathrm{pH}$, ionic composition, in addition to other necessary conditions for the survival of spermatozoa.

Most insects present only one spermatheca, as also observed in the queens of the species examined in this study: Atta laevigata, Atta sexdens sexdens, Atta sexdens piriventris, Acromyrmex coronatus and Cyphomyrmex muelleri. 
In these species, were confirmed that the spermatheca exhibit a similar morphology resembling a storage pouch described for insects in general, however, with two lobes partially jointed at the median portion of this structure. The same morphology was observed for the spermatheca of queens of the ants $A$. s. rubropilosa, A. balzani, A. landolti and A. l. balzani (Ortiz; Camargo-Mathias, personal communication). In $A$. coronatus and $C$. muelleri, the pouch is flatter that those of other species.

The presence of a fat body around organs has been reported for most insects, as observed surrounding the spermatheca of C. muelleri, however, it is unclear whether the fat body has any influence on the spermatheca or it only plays a role filling the abdomen. In the Orthoptera Locusta migratória, the spermatheca is also surrounded by a layer of fat body, probably acting as a protective structure in the pupa as well as in the adult ${ }^{[11]}$.

Another characteristic aspect of the spermatheca of queens of most insects is the presence of tracheae. According $^{[12]}$, these tracheae are responsible for gas exchanges, which are of extreme importance to maintain the integrity of epithelial cells and consequently fully functional.

The secretory cells of the spermatheca of most insects exhibit the membrane with abundant microvilli, which increase the cell surface for exchanges, indicating that the secretory epithelium may play a role in the reabsorption of the contents present in the lumen, in addition to cuticular support. Apical microvilli in the epithelial cells of the spermatheca have been described in some species of Blattaria ${ }^{[13]}$, Coleoptera ${ }^{[14,15]}$, Orthoptera $^{[11]}$ and in the stingless bee Melipona bicolor ${ }^{[16]}$. In the present study, similar structures, resemble a brush border, were observed in the internal secretory epithelium of $A$. s. piriventris.

In the spermatheca of these study species, as well as species of genus Atta and Acromyrmex examined by Ortiz and Camargo-Mathias (personal communication), regions probably playing a secretory role exhibited two morphologies: a) groups of cells forming structures resembling acini or filaments, located externally to the structure (spermathecal gland) and b) as a secretory epithelium internally lining the reservoir. Thus, depending on the species, the spermathecal secretion may be produced in three sites: a) in the spermathecal gland located in the external portion, b) in the secretory epithelium located in the internal portion of the reservoir or c) in both portions.

A spermathecal gland was observed in queens of $A$. laevigata, $A . \quad$ s. sexdens and $A$. coronatus and characterized by groups of cells and in C. muelleri, by filaments. The presence of this gland forming groups of cells resembling acini was also observed by Ortiz and Camargo-Mathias (personal communication) in the species $A$. s. rubropilosa and $A$. l. balzani. In the spermatheca of queens of $A$. s. piriventris, however, the external associated gland was absent, as also reported by Ortiz and Camargo-Mathias (personal communication) in the species $A$. balzani and $A$. landolti, suggesting a morphological similarity among the spermatheca of these ant species.

The spermatheca of the species A. laevigata, $A$. coronatus and C. muelleri present a reservoir with thin walls, due to the absence of an internal secretory epithelium, which was only present in $A$. s. sexdens, located only at the joining point of the spermathecal lobes and in A. s. piriventris, internally lining the entire spermatheca. The presence of an internal secretory epithelium in the spermatheca of queens of $A . s$. piriventris and $A . \quad S$. sexdens suggests that the physiology to maintain the sperm in viable conditions for egg fertilization might differ from those of $A$. laevigata, A. coronatus and C. muelleri, in which only the external spermathecal gland was observed.

Differences in thickness epithelium of the spermatheca are correlated with its roles, whether secretory or storing. In general, the epithelium of the spermatheca of insects is classified in three basic types, according to the location of secretory cells ${ }^{[17]}$. In the first type, found in Periplaneta americana, secretory cells are distributed throughout the entire wall of the reservoir $^{[13]}$, as also observed in our study for $A$. $s$. piriventris and the ant species A. l. balzani, A. balzani and $A$. landolti examined by Ortiz and CamargoMathias (personal communication). In the second type, gland cells are restricted to a particular region of the epithelium, as reported for Aedes aegypty ${ }^{[18]}$ and for $A$. $s$ s sexdens examined in our study. In the third type, gland cells form a gland distinct from the reservoir, as found in most Hymenoptera and several Coleoptera $^{[14,19]}$, in queens of $A$. laevigata, $A . s$. sexdens, A. coronatus and $C$. muelleri examined in present study and in A. s. rubropilosa described by Ortiz and Camargo-Mathias (personal communication).

According to the observed in the queens of $A$. laevigata, A. s. sexdens, A. coronatus and C. muelleri, were divided the spermatheca of these ant species in two distinct portions: a) a secretory portion represented by the spermathecal gland and consisted of cells responsible for the production the spermathecal liquid and b) a storing portion, represented by the reservoir consisted of a simple lining epithelium, where spermatozoa are stored and nourished until egg fertilization. Specifically in queens of $A$. s. sexdens, the secretory portion of the spermatheca was subdivided once more in: a) external secretory portion, represented by the spermathecal gland located externally to the structure and b) internal secretory portion, represented by the secretory epithelium located internally to the reservoir and restricted to the joining point of spermathecal lobes. Since in $A$. s. piriventris the spermatheca is not divided into two distinct portions and the epithelium producing the secretion is located internally to the reservoir, the secretion is produced and 

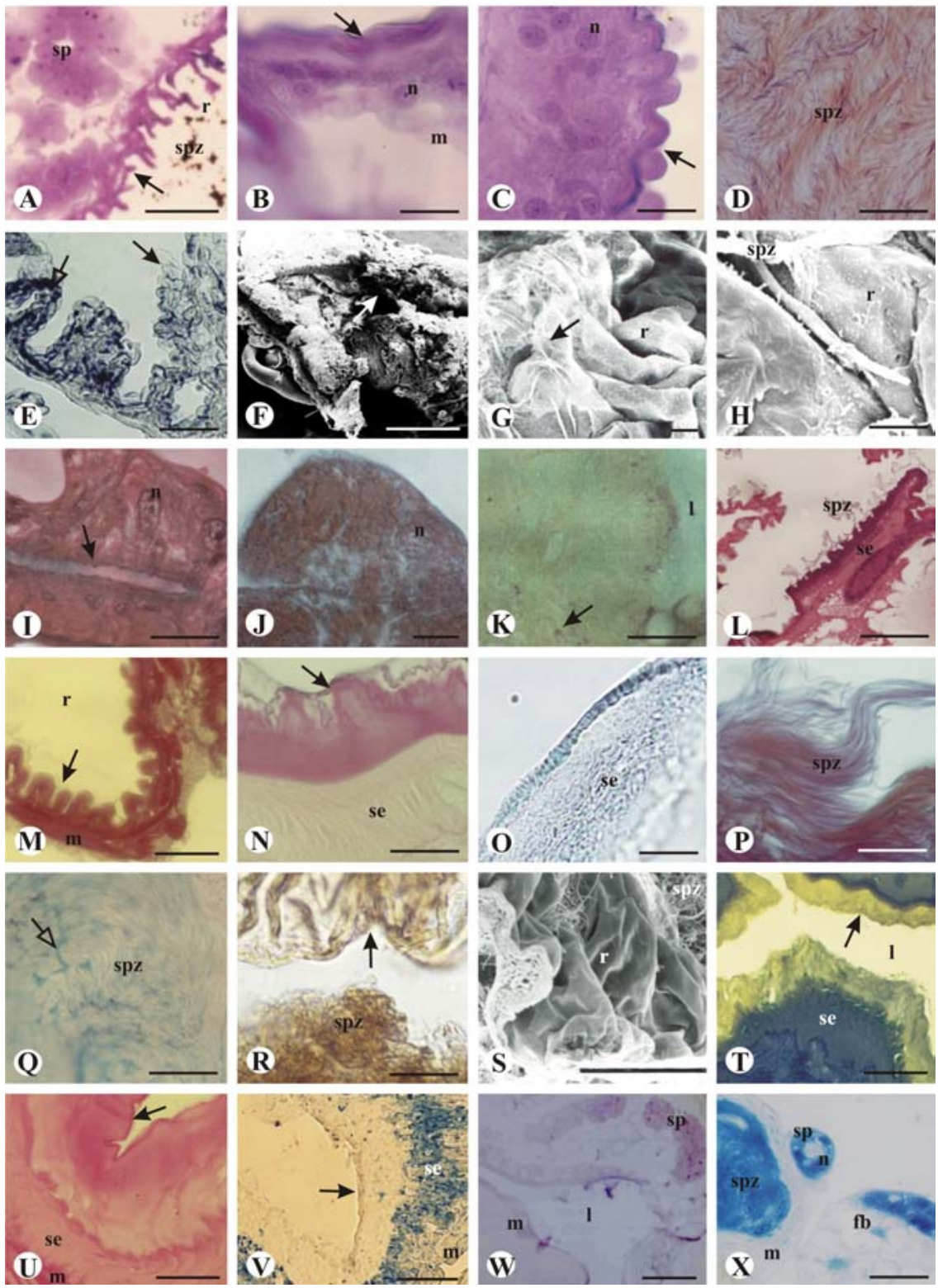

Fig. 2: A. General view of the spermatheca of A. laevigata stained with Ninhidrina Schiff, Scale bar $=100 \mu \mathrm{m}$. B. Detail of the reservoir wall with simple epithelium of scamous cells found in the spermatheca of A. laevigata stained with Ninhidrina Schiff, Scale bar $=20 \mu \mathrm{m}$. C. Portion of the stratified epithelium with cubical or polygonal cells found in the spermatheca of A. laevigata stained with Ninhidrina Schiff, Scale bar $=20 \mu \mathrm{m}$. D. Spermatozoa in the reservoir of the spermatheca of A. laevigata stained with Bromophenol Blue, Scale bar $=10 \mu \mathrm{m}$. E. Criosection of the spermatheca of A. laevigata stained with Sudan Black B, filled block arrow = cuticle, empty block arrow $=$ lipid accumulation at the cells of the coating epithelium, Scale bar $=20 \mu \mathrm{m}$. F. SEM of the spermatheca of $A$. s. sexdens, arrow $=$ interior of the reservoir, Scale bar $=0,5 \mu \mathrm{m}$. G. H. SEM of the interior of reservoir of $A$. s. sexdens, Scale bar $\mathrm{G}=0,025 \mu \mathrm{m}$, Scale bar $\mathrm{H}=8 \mu \mathrm{m}$. I. Detail of the spermathecal gland of $A$. s. sexdens stained with Hematoxyline and Eosin, arrow $=$ canaliculi, Scale bar $=10 \mu \mathrm{m}$. J. Detail of the spermathecal gland of $A$. $s$. sexdens stained with Ninhidrina Schiff, Scale bar $=10 \mu \mathrm{m}$. K. Detail of the spermathecal gland of $A$. s. sexdens stained with PAS/Alcian Blue, arrow $=$ intracitoplasmic granules PAS positive, Scale bar $=10 \mu \mathrm{m}$. L. General view of the spermatheca of $A$. s. sexdens stained with Hematoxyline and Eosin, Scale bar $=$ $100 \mu \mathrm{m}$. M. Detail of the reservoir wall composed by a simple epithelium of scamous cells found in the spermatheca of $A$. s. sexdens stained with Bromophenol Blue, Scale bar $=50 \mu \mathrm{m}$. N. Detail of the internal secretory epithelium of the spermatheca of $A$. s. sexdens stained with PAS/Alcian Blue, Scale bar $=10 \mu \mathrm{m}$. O. Detail of the internal secretory epithelium of the spermatheca of $A$. s. sexdens stained with Nile Blue, Scale bar $=20$ $\mu \mathrm{m}$. P. Spermatozoa in the reservoir of the spermatheca of $A$. s. sexdens stained with Bromophenol Blue, Scale bar $=10 \mu \mathrm{m}$. Q. Spermatozoa in the reservoir of the spermatheca of $A$. s. sexdens stained with PAS/Alcian Blue, empty block arrow = secretion with acid polysaccharide, Scale bar $=10 \mu \mathrm{m}$. R. Criosection of the reservoir wall of spermatheca of $A$. s. sexdens stained with Sudan Black B, Scale bar $=10 \mu \mathrm{m}$. S. SEM of the interior of reservoir of $A$. s. piriventris, Scale bar $=0,025 \mu \mathrm{m}$. T. General view of the spermatheca of $A$. s. piriventris stained with Bromophenol Blue, Scale bar $=50 \mu \mathrm{m}$. U. Detail of the internal secretory epithelium of the spermatheca of $A$. s. piriventris stained with PAS/Alcian Blue, Scale bar $=50 \mu \mathrm{m}$. V. Criosection of the spermatheca of $A$. s. piriventris stained with Nile Blue, Scale bar $=20 \mu \mathrm{m}$. W. General view of the spermatheca of A. coronatus stained with Hematoxyline and Eosin, Scale bar $=100 \mu \mathrm{m}$. X. General view of the spermatheca of $C$. muelleri stained with Bromophenol Blue, Scale bar $=50 \mu \mathrm{m} . \mathrm{sp}=$ secretory portion, $\mathrm{m}=$ musculature, $\mathrm{se}=$ internal secretory epithelium, $\mathrm{n}=$ nucleus of the epithelial cell, filled block arrow $=$ cuticle, $\mathrm{r}=$ reservoir, $1=$ lumen, $\mathrm{spz}=$ spermatozoa, $\mathrm{fb}=$ fat body cells 
discharged directly by exocytosis, with vesicles from the apical portion of the cytoplasm of secretory cells being released into the lumen of the spermatheca, without the participation of secretory cells externally to the organ. The same process has already been observed and described for the spermatheca of Rhodnius prolixus $^{[20]}$.

In A. laevigata, A. s. sexdens, $A$. coronatus and $C$. muelleri, the external secretory cells form a central collecting canaliculus, in which intracellular canaliculi open and collect the secretion produced by these cells, as well as transport them to the lumen of the reservoir. When we examined queens of $A$. s. sexdens, which exhibit two types of secretory epithelium, it is worth pointing out that canaliculi were only observed in cells of the spermathecal glands, while they were absent in the internal secretory epithelium. This indicates a different way, by exocytosis, to release the secretion produced by the cells of epithelia located internally to the reservoir.

Histochemically, these results revealed that in the spermatheca of two of three species of the genus Atta and that exhibit an internal secretory epithelium, $A . s$. sexdens and $A$. s. piriventris, the epithelium was strongly positive for proteins, indicating that this element is produced in large quantities and probably plays an important role in the composition of the secretion. The spermatheca of $C$. muelleri was also positive for this histochemical test, specially the spermathecal gland, the spermatozoa and the secretion present in the lumen of the reservoir, while the lining epithelium and muscles externally surrounding the spermatheca were weakly stained.

Tests demonstrating polysaccharides revealed that secretory cells, internally located in the spermatheca of A. s. sexdens and s. piriventris, were weakly stained or unstained in certain regions. This was also observed in the spermathecal gland of $A$. s. sexdens and laevigata. In the cytoplasm of these cells, only small PAS-stained deposits resembling fine granules were observed, indicating low levels of production of these elements in the spermatheca of the three species. ${ }^{[21]}$ reported that the spermatheca of Schistocerca americana and Dissosteira carolina were weakly to moderately stained by PAS, while the cuticle lining this structure was strongly positive for acidic polysaccharides.

In the spermatheca of $A$. laevigata, a large amount of polysaccharides was observed in the cytoplasm of cells of the epithelium lining the reservoir, which does not play a secretory role in the production of components for the maintenance of spermatozoa in this species, suggesting that, since the cuticle is a structure that exhibits large quantities of polysaccharides and proteins, these polysaccharides might be produced by the cells of this epithelium.

The low levels of polysaccharides in the spermatheca of the studied species of the genus Atta, as well as those of other insects, suggest that these elements might take part only in the formation of complexes with other compounds, such as glycoproteins, which might play a role in the maintenance of spermatozoa, providing them a s source of energy while stored inside these structures and mainly, providing energy necessary for their metabolism, including during the time near fertilization.

Tests performed in these study demonstrated that lipids were more abundant in the spermatheca of $A$. $s$. piriventris, although some staining was observed in the secretory cells of $A$. s. sexdens and A. laevigata. Weak staining by Sudan Black B was also observed by ${ }^{[21]}$ in the spermatheca of $S$. americana e D. carolina.

These results obtained for lipids showed a low production of these elements in spermathecae, suggesting that, similarly to polysaccharides, they might be produced only to form complexes with other compounds. The small amounts of polysaccharides and lipids found in the spermathecae of ants of the genus Atta, as opposed to the large quantities of proteins, suggest that the spermathecal secretion primarily consists of proteins, but that form complexes with lipids and polysaccharides.

In some studies on the reproductive system of bees, reported that phospholipids can also used as a source of energy, although in this case, oxidative energy for respiration ${ }^{[22]}$. The use of this compound might be associated to the fact that, under aerobic conditions, the spermatozoon might be mobile for at least three hours before ejaculation.

There are few studies specifically on the secretion produced by spermathecal secretory cells, as well as the secretion present in the spermatheca. Some of them, however, have demonstrated that the secretion present in the lumen of the spermatheca, product of secretory cells, is of glycoprotein nature ${ }^{[18,23-25]}$. The spermatozoa utilize this secretion as a source of energy and are in constant movement inside this structure.

The spermatozoa of most insects have been described as elongated and filamentous structures ${ }^{[26,27]}$, as also observed in all ant species examined in the present study. Histochemical tests revealed that spermatozoa of these ants species are elongated and uniform structures consisted primarily of polysaccharides and proteins, as lipids were only observed in the membrane of spermatozoa of $A$. laevigata and A. s. sexdens.

These preliminary morphological datas on the spermatheca of queens of $A$. s. sexdens, A. s. piriventris, A. laevigata, A. coronatus and $C$. muelleri revealed that the latter three species present only an external secretory epithelium (spermathecal gland); A. s. sexdens exhibits an external as well as an internal secretory epithelium; and $A$. $s$. piriventris presents only an internal secretory epithelium.

Since A. s. piriventris exhibits a secretory epithelium only in the internal region of the spermatheca, this suggests that the spermatheca itself might be self-sufficient to produce all elements of secretion in order to maintain the spermatozoa viable, without the need of exogenous elements from the hemolymph. The little or no dependence on exogenous 
compounds in relation to the spermatheca that contribute to provide a suitable microhabitat for the spermatozoa until egg fertilization might increase the chances of survival of the species, even during unfavorable environmental conditions.

\section{ACKNOWLEDGEMENTS}

This work by supported by FAPESP (Fundação de Amparo à Pesquisa do Estado de São Paulo), grant $n^{\circ}$ 03/05485-0. The authors wish to thanks to Antônio Teruyoshi Yabuki, Mônika Iamonte, Gerson Mello Souza and Cristiane Márcia Mileo for their technical support.

\section{REFERENCES}

1. Thornhill, R. and J. Alcock, 1983. The evolution of insect mating systems. Harvard Press, Cambridge, Mass.

2. Chapman, R.F., 1998. The Insects: Structure and Function. New York, Elsevier, pp: 770.

3. Davey, K.G., 1985. The Female Reproductive Tract. Kerkut, G.A. and Gilbert, L.I. (Ed). Comprehensive Insect Physiology: Embryogenesis and Reproduction. Pergamon Press.

4. Eberhard, W.G., 1996. Female control: sexual selection by cryptic female choice. Princeton: Princeton University Press.

5. Happ, G.M. and C.M. Happ, 1970. Fine structure and histochemistry of the spermathecal gland in the mealworn beetle, Tenebrio molitor. Tissue Cell., 2: 443-466.

6. Grodner, M.L. and W. Steffens, 1978. Evidence of a chemotatic substance in the spermathecal gland of the boll weevil. Trans. Am. Microsc. Soc., 97: 116-120.

7. Gillot, C., 2003. Male acessory gland secretions: Modulations of female reproductive physiology and behaviour. Annu. Rev. Entomol., 48: 163-184.

8. Kaulenas, M.S., 1992. Insect Accessory Reproductive Structures: Function, Structures and Development. Berlin, Heidelberg: Springer-Verlag.

9. Villavaso, E.J., 1975. The role of the spermathecal gland of the boll weevil Anthonomus grandis. J. Insect. Physiol., 21: 1457-1462.

10. Berry, D.J., 1985. Material direction of oogenesis and early embryogenesis in insects. Annu. Rev. Entomol., 27: 205-227.

11. Lay, M., D. Zissler and R. Hartmann, 1999. Ultrastructural and functional aspects of the spermatheca of the African Migratory Locust Locusta migratoria migratorioides (Reiche and Fairmaire) (Orthoptera: Acrididae). Int. J. Insect Morphol. Embryol., 28: 349-361.

12. Poole, H.K., 1970. The wall structure of the honey bee spermatheca with comments about its function. Ann. Entomol. Soc. Am., 63: 1625-1628.

13. Gupta, B.L. and D.S. Smith, 1969. Fine structural organization of the spermatheca in the cockroach Periplaneta americana.Tissue and Cell., 1: 295324.
14. Happ, G.M. and C.M. Happ, 1975. Fine structure of the spermathecae of the mealworm beetle Tenebrio molitor L. Cell Tissue Res., 162: 253269.

15. Tombes, A.S. and R.M. Roppel, 1972. Ultrastructure of the spermatheca of the granary weevil Sitophilus granarius (Coleoptera, Curculionidae). Int. J. Insect. Morphol. Embryol., 1: 141-152.

16. Cruz-Landim, C. and J.E. Serrão, 2002. Ultrastructure of the spermathecal gland of Melipona bicolor Lep. (Hymenoptera, Apinae, Meliponini). Braz. J. Morphol. Sci., 1: 9-16.

17. Gillot, C., 1988. Insecta. In Reproductive Biology of Invertebrates. Vol. III. Acessory Sex glands. Edited by K.G. Adiyodi and R.D. Adiyodi. John Wiley \& sons Ltd., U.K., p. 356-471.

18. Clements, A.N. and S.A Potter, 1967. The fine structure of the spermathecae and their ducts in the mosquito Aedes aegypti. J. Insect. Physiol., 13: 1825-1836.

19. Dallai, R., 1975. Fine structure of the spermathecae of Apis Mellifera. J. Insect Physiology., 21: 89109.

20. Camargo, J.M.F. and M.L.S. Mello, 1970. Anatomy and histology of the genital tract, spermatheca, spermathecal duct and glands of Apis mellifera queens (Hymenoptera: Apidae). Apidologie., 1: 351-373.

21. Gardner, G.E., 2004. Morphological and histological aspects of the spermatheca as they relate to sperm organization in the grasshopper species Schistocerca americana and Dissosteira carolina (Orthoptera: Acrididae). 2004, 41f. Thesis (Degree of Master of Science)-Faculty of North Carolina State University, Raleigh.

22. Blum, M.S., Z. Glowska and S. Taber, 1967. Composition and possible significance of fatty acids in the lipid classes in honey bee semen. Journal of Insect Physiology., 13: 1301-1308.

23. Ahmead, L. and C. Gillot, 1982a. The spermathecae of Melanoplus sanguinipes (Fabr.) I. Morphology, histology and histochemistry. Int. J. Invert. Rep., 4: 281-295.

24. Ahmead, L.and C. Gillot, 1982b. The spermathecae of Melanoplus sanguinipes (Fabr.) II. Ultrastructure. Int. J. Invert. Rep., 4: 297-309.

25. Bhatinagar, R.D. and A.J. Musgrave, 1971. Aspects of the histophysiology of the spermathecal gland of Stophilus granarius (L) (Coleóptera). Canad. J. Zool., 49: 275-277.

26. Baccetti, B., 1972. Insects sperm cell. Advances in Insects Physiology, London., 9: 315-395.

27. Dallai, R. And B. Afzelius, 1993. Axonemal structure and insect phylogeny. Boll. Zool., 60: 423-429. 